REPORTS OF MORPHOLOGY
Official Journal of the Scientific Society of Anatomists,
Histologists, Embryologists and Topographic Anatomists
of Ukraine
journal homepage: https://morphology-journal.com

\title{
Electron microscopic changes of the testis germinal epithelium after an experimental thermal trauma in the application of cryo- lyophilized xenograft skin substrate
}

Volkov K.S., Muha S.Yu.

SHEl "I. Ya. Horbachevsky Ternopil State Medical University Ministry of Health of Ukraine", Ternopil, Ukraine

\section{ARTICLE INFO}

Received: 3 October, 2018

Accepted: 2 November, 2018

UDC: $611.631: 616$ - 001.19: 612.08

\section{CORRESPONDING AUTHOR}

e-mail: KVolkov@gmail.com Volkov K.S.

\begin{abstract}
Deep, large area of thermal trauma of the skin leads to significant morphofunctional changes in organs in the composition of the burned organism. However, condition of the central organ of the male reproductive system - testicle after burns and, especially, in the treatment of thermally damaged areas of the skin remain poorly understood. The purpose of this study was to establish an ultrastructural re-organization of testis germinal epithelium cells in the stages of toxemia and septicotoxemia following an experimental thermal trauma when using xenograft skin substrate. The studies were carried out on 35 sexually mature white male rats, which were divided into three groups: 1 - intact animals (5 rats), 2 - animals with burn injury (15 rats), 3 - animals with burn injury, for which were used xenograft skin substrate (15 rats). The burn was applied under ketamine anesthesia with copper plates, heated in boiling water, on 18$20 \%$ shaved body surface of animals. Early necrectomy of the damaged areas of skin was carried out 1 day after the thermal burn. The formed wounds were covered with cryo-lyophilized xenograft skin substrate. Experimental animals were decapitated at 7, 14 and 21 days of the experiment (early, late toxemia and septicotoxemia). The material sampling for electron microscopy was carried out in accordance with a generally accepted methodology. It is established that in the stage of early toxemia (7 days of experiment) there are adaptive-compensatory changes and signs of destruction of spermatogenic cells of testis. In the stages of late toxemia and septicotoxemia (14 and 21 days of the trial), significant destructive changes occur in all components of the seminiferous tubules of the organ. Electron microscopically found that the closure of the burn wound after the early necrectomy of cryo-lyophilized xenograft skin substrate in severe experimental burn injury in the early stages of the experiment significantly reduces the damage of testis germinal epithelium of experimental animals and activates regenerative processes. This contributes to a significant improvement in the ultrastructure of the components of the convoluted tubules of the organ in the late stages of the experiment.

Keywords: testicle, electron microscopic changes, experimental thermal trauma, cryo-lyophilized xenograft skin substrate.
\end{abstract}

\section{Introduction}

An urgent medical problem is the establishment of a reorganization of organs of the reproductive system under the influence of external factors that are toxic in nature [18]. It is known that severe thermal trauma of the skin causes significant morphofunctional changes in the systems and organs of the organism, including the reproductive system $[3,5,13]$. The analysis of scientific literature has shown that still remain poorly understood condition of testis (the central organ of the male reproductive system) after burns of body.

According to modern ideas, one of the immediate causes of significant morphofunctional changes in organs and tissues in burns is exo- and endogenous intoxication $[1,14]$. The products of decay of tissues, specific and nonspecific toxins are a trigger mechanism for burn infections, and, subsequently, the development of septicotoxemia $[8,9]$. Therefore, from the theoretical and practical point of view, it is important to conduct studies to 
study the changes of the testis germinal epithelium, the course of compensatory adjustment and regenerative processes in them at the closure of the burn wound after the early necrectomy of the affected skin sections with crushed cryo-lyophilized xenograft skin substrate $[2,10,11]$.

The purpose of this work was to establish an ultrastructural reorganization of testis germinal epithelium cells in the stages of toxemia and septicotoxemia after an experimental thermal trauma when using xenograft skin substrate.

\section{Materials and methods}

Experiments were conducted on 35 sexually mature white male rats divided into three groups: 1 - intact animals (5 individuals), 2 - animals with burn injury (15 individuals), 3 - animals with burn injury, which were used as xenograft skin substrate (15 individuals). The burn was applied under ketamine anesthesia with copper plates heated in boiling water on $18-20 \%$ shaved body surface of animals. Early necrectomy of damaged areas of skin was carried out 1 day after the thermal burn. The formed wounds were covered with cryo-lyophilized xenograft skin substrate.

In conducting research, the international rules and principles of the "European Convention for the Protection of Vertebrate Animals used for Experiments and for Other Scientific Purposes" (Strasbourg, 1986) and "General Ethical Principles of Animal Experiments" (Kyiv, 2001) and the Law of Ukraine No. 3447 "On the Protection of Animals from Cruel Treatment - 2006" were followed. Histological examination of the skin testified to the development of the burn of the third degree.

Experimental animals were decapitated at 7, 14 and 21 days of the experiment, which met the terms of early, late toxemia and septicotoxemia. The material sampling for electron microscopic studies was carried out in accordance with the generally accepted method [16]. The small pieces of testis germinal epithelium were fixed in $2.5 \%$ glutaraldehyde solution with an active medium $\mathrm{pH}$ of $7.2-7.4$ prepared on phosphate buffer. The postfixation of the material was carried out with a $1 \%$ solution of osmium tetrachloride, after which it was dehydrated in propylene oxide and poured into a mixture of epoxy resins with araldite. Ultrathin sections made on ultramicrotome LKB-3 (Sweden) were contrasted with $1 \%$ aqueous uranyl acetate solution and lead citrate by Reynolds method and studied by electron microscope PEM-125K.

\section{Results}

Electron microscopic studies on day 7 after a thermal trauma found that the walls of the seminiferous tubules appear thickened due to the swelling of the fibrous layer and the sites of contraction of the myoid cells. In sustentacular cells there is enlightenment of the cytoplasm, hypertrophy of the mitochondria, damage to the integrity of the crist?. Part of the nuclei have uneven contours of the nuclear membrane, increased nuclear pore. Germinal epithelium cells are altered, spermatogonia is present with signs of mitosis, but less than in the testicles of the intact group of animals. Spermatocytes are not densely located due to enhanced intercellular spaces, in their cytoplasm vacuole-like structures are available in different sizes (Fig. 1).

Part of spermatocytes with elevated osmiophilic of karyoplasm and cytoplasm, deformed nuclei. In spermatids and spermatozoa, poorly contoured acrosome, high electron density of nuclei and damage to nuclear membrane (Fig. 2).

At 14 and especially 21 days after thermal trauma in the structural components of seminiferous tubules there is an increase in ultrastructural changes. There are heterogeneous changes in the myoid cells. In addition to cells with electronically bright, edematous cytoplasm, cells with osmophilic cytoplasm and picnotically altered nuclei are detected. Organelles in them are destructively altered.

Submicroscopically, in the late stages of the trial, a significant destruction is found in sustentacular cells. Incorrect form of their nuclei includes osmiophilic

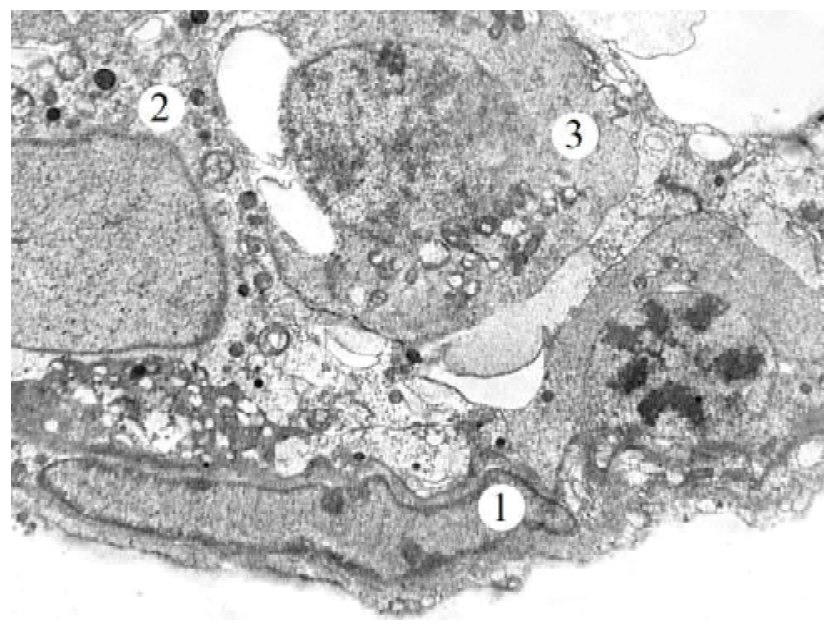

Fig. 1. Ultrastructural changes of the animal's seminiferous tubules on 7 day after a thermal trauma. Wall of tubules (1), Sertoli cell (2), primary spermatocyte (3). x13000.

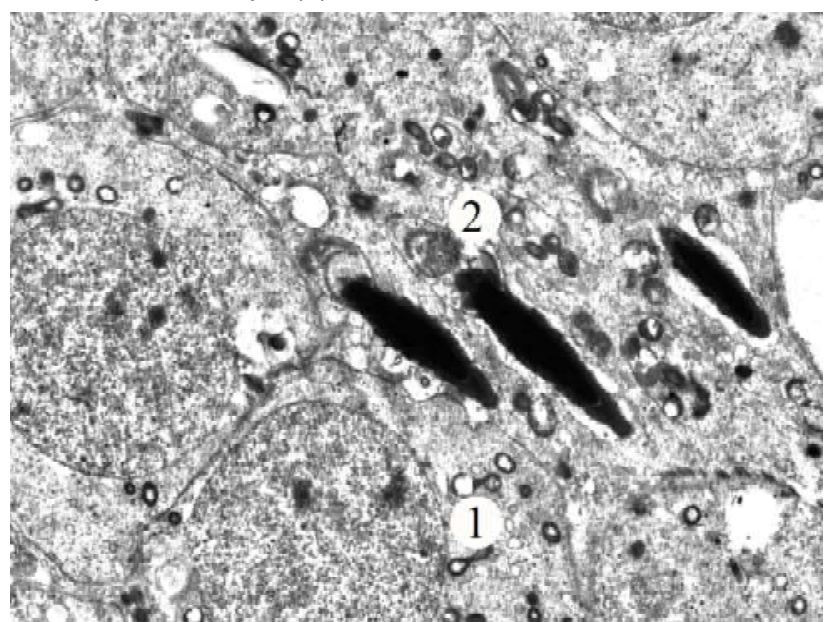

Fig. 2. Submicroscopic state of the spermatogenic cells of the testicle of the animal for 7 days after a thermal trauma. Primary spermatocyte (1), spermatids (2). x13000. 
karyoplasm. In the cytoplasm of elevated electron density, organelles were poorly contoured, vacuole-like structures were present (Fig. 3).

In the spermatogenic cells, there were cells with signs of myotic division. In the part of spermatids and spermatozoa, poorly contoured acrosome, high electron density of nuclei and damage to nuclear membrane. A part of the cells was with increased osmiophilic of karyoplasm and cytoplasm, deformed nuclei. Expanded intercellular spaces, spermatocytes are not densely located, vacuole-shaped structures of varying sizes are available in their cytoplasm. Such a condition of the germinal epithelium characterizes significant violations of spermatogenesis.

Electron microscopic examination of the testicles of animals after 7 days of burning under the use of xenograft skin substrate revealed an improvement in their ultrastructure. Available spermatogonia with signs of mitosis, primary and secondary spermatocytes include round nucleus having euchromatin and small breasts of heterochromatin in the structure of the karyoplasm, and partly damaged organelles in the cytoplasm (Fig. 4). Spermates and spermatozoa are also less altered than in the group of animals with burns.

Sub-microscopic studies in the late terms of the experiment found that, especially at 21 day, there was a significant improvement in the state of the structural components of seminiferous tubules. The bodies of supporting cells are clearly contoured, they have a large cone-shaped body with sprouts located on the base of the basement membrane. A significant area of the cytoplasm of Sertoli cell includes the granulosa endoplasmic reticulum tubule and small vesicles of rough endoplasmic reticulum. Small mitochondria have a long or round shape depending on the plane of the cross-section. In the average electron density of the matrix and little crist?. Available dictyosomes of the Golgi complex, lysosomes, mainly primary, lipid inclusion, bubbles and vacuoles, mainly in adlucent compartment. Plasmalemma of sustentacular cells is in contact with the germinal epithelium.

In the germinal epithelium there are cells with signs of mitotic division. Primary spermatocytes have a large area of the cytoplasm that is electronically light, including many free ribosomes and small unevenly located mitochondria. In the nucleus of the cells, there are meiosis figures, varying degrees of regions of the condensed chromosomes are detected and, in particular, they are thickened in the stage of pachytene and diakinesis.

Secondary spermatocytes are smaller in size, include round eucharomatic nuclei, a small area of the cytoplasm and localized closer to the lumen of the seminiferous tubules. In spermatids and spermatozoa, the acrosome is well contoured, a high electron density of nuclei is present, and the mitochondrial vagina is formed (Fig. 5).

This condition of the germinal epithelium characterizes its normalization and the restoration of the phase nature of spermatogenesis.

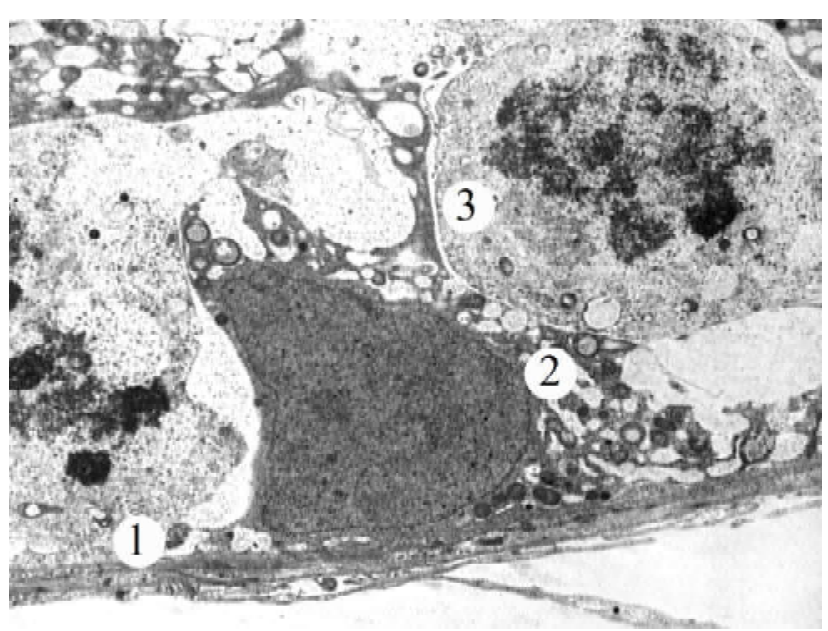

Fig. 3. Ultrastructural changes in the animal's seminiferous tubules on the 21 st day after a thermal trauma. Wall of tubules (1), Sertoli cell (2), primary spermatocyte (3). x7000.

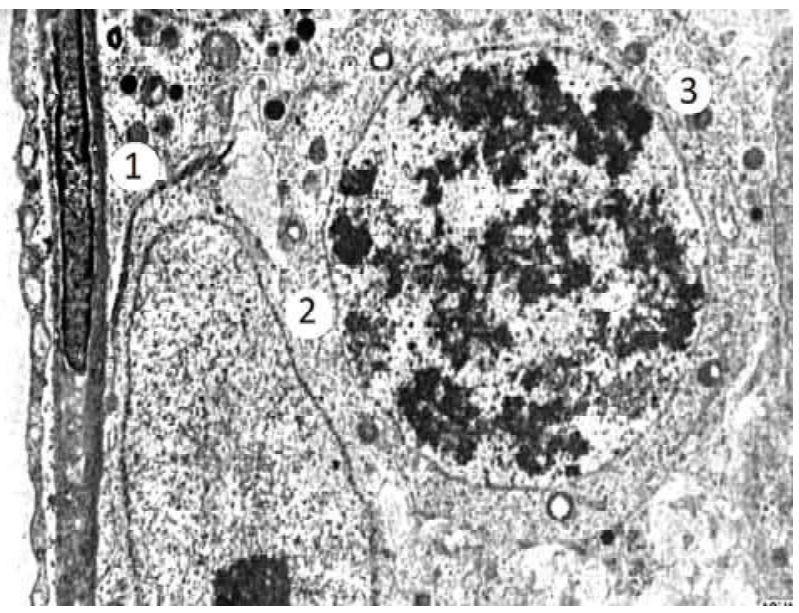

Fig. 4. Ultrastructural state of the seminiferous tubules of the animal for 7 days after the thermal trauma with the use of cryolyophilized xenograft skin substrate. Wall of tubules (1), Sertoli cell (2), primary spermatocyte (3). x12000.

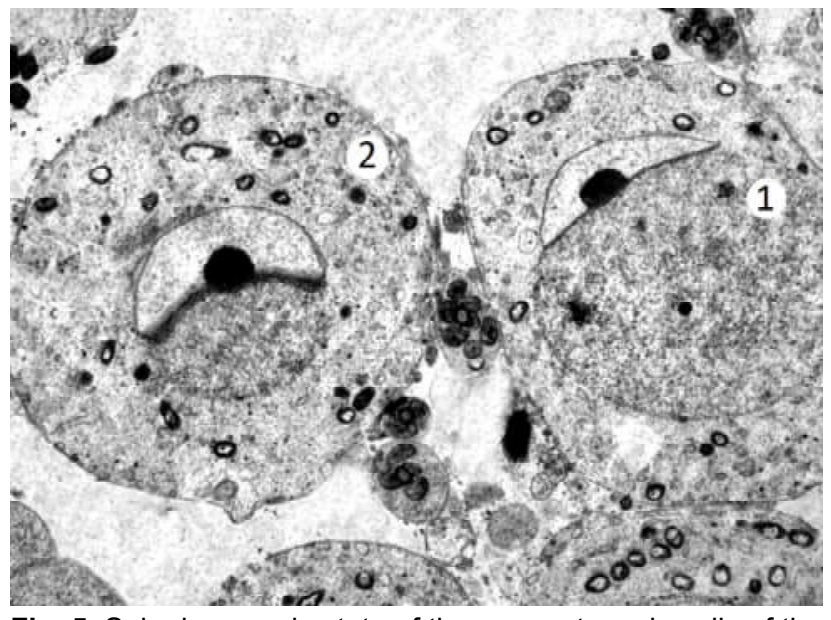

Fig. 5. Submicroscopic state of the spermatogenic cells of the seminiferous tubules animal for 21 days after the thermal injury of the animal with the use of cryo-lyophilized xenograft skin substrate. The nucleus (1) and the cytoplasm (2) of spermatids. x9000. 


\section{Discussion}

The morphological state of the structural components of the testicles and their reproductive function greatly depend on the effect of the damaging factors [17]. Specific and nonspecific toxins resulting from the decomposition of skin tissues after severe thermal trauma cause significant changes in the germinal epithelium ultrastructure and, in particular, in the stages of early and late toxemia. In the seminiferous tubules, the submicroscopic organization of Sertoli cells is affected, which affects the process of the formation of germ cells. Their destructive changes after a thermal trauma are established in all phases of spermatogenesis in the testes of the experimental group.

Significant changes in the area of burn of the skin and internal organs in the body systems are established in many studies $[6,12,15,19]$. Therefore, it was advisable to conduct early necrectomy of wound-affected areas of the skin and use of cryo-lyophilized xenograft skin substrate on wounds. The electron microscopically positive effect of this xenograft skin substrate on the ultrastructure of all components of the testis germinal epithelium and, especially, in the late experiment (21 days) was proved.

The reduction of histological changes in the use of such a factor after skin burns in the experiment is established in studies of the structure of the myocardium, lungs, kidneys, liver and other internal organs of the experimental animals $[10,11]$.

Thus, severe, large-scale thermal lesions of the skin

\section{References}

[1] Biguniak, V. V. \& Folded, M. Yu. (2004). Thermal defeats. Ternopil: Ukrmedkbook.

[2] Eick, B. G., \& Denke, N. J. (2018). Resuscitative Strategies in the Trauma Patient: The Past, the Present, and the Future. J. Trauma Nurs., 25(4), 254-263. doi:10.1097/ JTN.0000000000000383

[3] Evers, L. H. (2010). The biology of burn injury. Exp. Dermatol., 19(2), 9, 777-783 doi:10.1111/j.1600-0625.2010.01105.x

[4] Gavryluk, A. O., Galunko, G. M., Chereshniuk, I. L., Tikholaz, V. O., Cherkasov, E. V., Dzevulska, I. V., \& Kovalchuk O. I. (2018). Indicators cell cycle and DNA fragmentation in cells of small intestine mucosa 14, 21 and 30 days after skin burns on the background of preliminary infusion of solution lactoprotein with sorbitol or HAES-LX 5\%. World of Medicine and Biology, 1(63), 104-108 doi:10.26724/2079-8334- 2017-4-62-104-108

[5] Gembitsky, E. V., Klyachkin, L. M., \& Kirilov M. M. (1994). Pathology of internal organs in trauma. M.: Medicine.

[6] Gunas, I. V., Guminskiy, Yu. I., Ocheretna, N. P., Lysenko, D. A., Kovalchuk, O. I., Dzevulska, I. V., \& Cherkasov, E. V. (2018). Indicators cell cycle and dna fragmentation of spleen cells in early terms after thermal burns of skin at the background of introduction $0.9 \% \mathrm{NaCl}$ solution. World of Medicine and Biology, 1(63), 116-120. doi: 10.26.724/2079-8334-2018-1-63-116-120

[7] Janak, J. C., Clemens, M. S., Howard, J. T., Le T. D., Cancio, L. C., Chung, K. K., Gurney, J. M., Sosnov, J. A., Stewart, lan J. (2018). Using the injury severity score to adjust for comorbid trauma may be double counting burns: implications for burn research. Burns, 44, 8, 1920-1929. doi: 10.1016/ j.burns.2018.03.012 require the implementation of modern therapeutic measures to activate and accelerate regenerative processes not only for the healing of burn wounds, but also for the reduction of pathological changes and normalization of the morphofunctional state of the internal organs of the body [4, 7].

The obtained scientific results can be used for further investigations of the condition of the structural components of the testicles under the conditions of applying corrective factors in the experimental thermal trauma.

\section{Conclusions}

1. In the early term after the thermal trauma (7 day of the experiment), ultrastructural changes have signs of destruction of testis germinal epithelium cells and are adaptive-compensatory. In the long term after the thermal lesions (14 and 21 days of the trial), under conditions of endogenous intoxication, deep destructive changes of the germinal epithelium develop, and the inhibition of reparative regeneration is present.

2. Coating of the burn wound with crushed cryo-lyophilized xenograft skin substrate after excision of necrotizing tissues from the site of damage significantly reduces the destructive changes of cells of the germinal epithelium. The best preservation of the intracellular components of Sertoli cells and the activation of regeneration contributes to the relative normalization of the testis structure in the late stages of the experiment.

[8] Klimenko, M. O. \& Netyukhailo, L. G. (2009). Burn disease (pathogenesis and treatment). Poltava $118 \mathrm{p}$.

[9] Kozinets, G. P., Kovalenko, G. P., \& Slesarenko, S. V. (2006). Burn sickness. Art of treatment, 12, 9-15.

[10] Nagaychuk, V. I. (2010). Modern approaches to helping patients with burns. Art of treatment, 5, 24-27.

[11] Nebesna, Z. M. (2015). Morphological state of the heart, liver and lungs after experimental thermal trauma under conditions of application of crushed substrate of cryolophilized xenose. World of Medicine and Biology, 3(51), 99-103.

[12] Ocheretna, N. P., Guminskiy, Yu. I., \& Gunas, I. V. (2018). Indicators of cell cycle and dna fragmentation of spleen cells in early terms after thermal burns of skin on the background of using "lactoprotein with sorbitol" or HAES-LX-5\%. Bulletin of scientific research, 1, 141-146. doi:10.11603/24158798.2018.1.8627

[13] Osadchaya, O. I., Boyarskaya A. M. \& Sheyman, B. S. (2008). Effect of enterosorption on the content of pro- and antiinflammatory mediators in severe thermal trauma. Internal Medicine, 16(3), 76-78.

[14] Paramonov, B. A., Porembsky, Ya. O., \& Yablonsky, V. G. (2000). Burns: A Guide for Doctors. SPb.: Spec. lit.

[15] Regas, F. C., \& Ehrlich, H. P. (1992). Elucidating the vascular response to burns with a new rat model. J. Trauma, 32(5), 557-563. PMID:1588642

[16] Sarkisov, D. S., \& Perova, Yu. L. (Ed.). (2002). Microscopic technique. M.: Medicine.

[17] Stravsky T. Y. (2015). Morphological and functional characteristics of the adjustment of parenchyma testis of 
rats at metered stenosis of spermatic cord. Bulletin of scientific research, 4, 110-112. doi:10.11603/1681-276X.2015.4.5662

[18] Voloshina, I. S. (2011). Contemporary ideas about the morphogenesis of the internal organs of the male reproductive system under the influence of various factors. Ukrainian morphological almanah, 9(4): 155-160.

[19] Williams, F. N., Herndon, D. N., Suman, O. E., Lee, J. O., Norbury, W. B., Branski, L. K., ... Jeschke, M. G. (2011). Changes in cardiac physiology after severe burn injury. J. Burn Care Res., 32(2), 269-274. DOI: 10.1097/BCR.0b013e31820aafcf

ЕЛЕКТРОННО-МІКРОСКОПІЧНІ ЗМІНИ СПЕРМАТОГЕННОГО ЕПІТЕЛІЮ ЯЄЧОК ПІСЛЯ ЕКСПЕРИМЕНТАЛЬНОЇ ТЕРМІЧНОЇ ТРАВМИ ПРИ ЗАСТОСУВАННІ СУБСТРАТА КРІОЛІОФІЛІЗОВАНОЇ КСЕНОШКІРИ

Волков К.С., Муха С.Ю.

Глибока, велика за площею термічна травма шкіри призводить до значних морфоофункціональних змін органів в складі систем обпеченого організму. Проте, маловивченим залишається при опіках иентральний орган чоловічої статевої системи - яєчко i, особливо, при лікуванні термічно пошкоджених ділянок шкіри. Метою цього дослідження було встановлення ультраструктурної реорганізації клітин сперматогенного епітелію яєчок в стадіях токсемії та септикотоксемії після експериментальної термічної травми при застосуванні субстрата ксеношкіри. Дослідження проведені на 35 статевозрілих білих щурах-самиях, які були розподілені на три групи: 1 - інтактні тварини (5 особин), 2 - тварини з опіковою травмою (15 особин), 3 - тварини з опіковою травмою, яким застосовували субстрат ксеношкіри (15 особин). Опік наносили під кетаміновим наркозом мідними пластинами, нагрітими у киплячій воді, на 18-20\% епільованої поверхні тіла тварин. Ранню некректомію пошкоджених ділянок шкіри проводили через 1 добу після нанесення термічного опіку. Рани, які утворились, покривали кріоліофрілізованим ксенодермальним субстратом. Піддослідних тварин декапітували на 7, 14 та 21 доби експерименту, що відповідно темінам ранньої, пізньої токсемії та септикотоксемії. Забір матеріала для електронно-мікроскопічних досліджень проводили згідно із загальноприйнятою методикою. Встановлено, що в стадії ранньої токсемії (7 доба досліду) наявні пристосувально-компенсаторні зміни та ознаки деструкції клітин сперматогенного епітелію яєчок. У стадіях пізньої токсемії та септикотоксемії (14 і 21 доби досліду) відбуваються значні деструктивні зміни всіх компонентів звивистих канальців органу. Електронно-мікроскопічно встановлено, що закриття опікової рани після проведення ранньої некректомії субстратом кріоліофрілізованої ксеношкіри за умов тяжкої експериментальної опікової травми вже в ранні терміни досліду суттєво зменшує пошкодження сперматогенного епітелію яєчок піддослідних тварин $і$ активізує регенераторні процеси. Це сприяє суттєвому покращенню ультраструктури компонентів звивистих канальців органу в пізні терміни експерименту. Ключові слова: яєчко, електронно-мікроскопічні зміни, експериментальна термічна травма, субстрат кріоліофілізована ксеношкіра.

\section{ЭЛЕКТРОННО-МИКРОСКОПИЧЕСКИЕ ИЗМЕНЕНИЯ СПЕРМАТОГЕННОГО ЭПИТЕЛИЯ ЯИЧЕК ПОСЛЕ ЭКСПЕРИМЕНТАЛЬНОЙ ТЕРМИЧЕСКОЙ ТРАВМЫ ПРИ ПРИМЕНЕНИИ СУБСТРАТА КРИОЛИОФИЛИЗИРОВАННОЙ КСЕНОКОЖИ \\ Волков К.С., Муха С.Ю.}

Глубокая, большая по площади термическая травма кожи приводит к значительным морфофункциональным изменениям органов в составе систем обожженного организма. Но малоизученным при ожогах остается центральный орган мужской половой системы - яичко и, особенно, при лечении термически поврежденных участков кожи. Целью этого исследования было установление ультраструктурной реорганизации клеток сперматогенного эпителия яичек в стадиях токсемии и септикотоксемии после экспериментальной термической травмы при использовании субстрата ксенокожи. Исследования проведены на 35 половозрелых белых крысах-самцах, которые были распределены на три группы: 1 - интактные животные (5 особей), 2 - животные с ожоговой травмой (15 особей), 3 - животные с ожоговой травмой, которым применяли субстрат ксенокожи (15 особей). Ожог наносили под кетаминовым наркозом медными пластинами, нагретыми в кипящей воде, на 18$20 \%$ эпилированой поверхности тела животных. Некрэктомию поврежденных участков кожи проводили через 1 день после нанесения термического ожога. Раны, которые образовались, покрывали криолиофилизированным ксенодермальным субстратом. Подопытных животных декапитировали на 7, 14 та 21 день эксперимента, что соответствует срокам ранней, поздней токсемии и септикотоксемии. Забор материала для электронно-микроскопических исследований проводили согласно общей существующей методики. Выявлено, что в стадии ранней токсемії (7 день опыта) присутствуют признаки деструкции клеток сперматогенного эпителия яичек и приспособительно-компенсаторные изменения. В стадиях поздней токсемии и септикотоксемии (14 и 21 день опыта) происходят значительные деструктивные изменения всех компонентов извитых канальцев органа. Электронно-микроскопически установлено, что закрытие ожоговой раны после проведения ранней некрэктомии субстратом криолиофилизированой ксенокожи при тяжелой экспериментальной ожоговой травме уже в ранние сроки опыта существенно уменьшает повреждение сперматогенного эпителия яичек экспериментальных животных, активизирует регенераторные процесы. Это способствует существенному улучшению ультраструктуры компонентов извитых канальцев органа в поздние сроки эксперимента.

Ключевые слова: яичко, электронно-микроскопические изменения, экспериментальная термическая травма, субстрат криолиофилизированная ксенокожа. 